些

Free to Authors and Readers
DOAJ Seal

\title{
Preparation of substituted alkoxypyridines via directed metalation and metal-halogen exchange
}

\author{
Ibrahim D. Bori and Daniel L. Comins*
}

Department of Chemistry, North Carolina State University, Raleigh, North Carolina 27695-8204, USA

E-mail: dlcomins@ncsu.edu

Dedicated to Professor Peter A. Jacobi on the occasion of his retirement from Dartmouth College

Received 01-08-2021

Accepted 02-02-2021

Published on line 02-04-2021

\section{Abstract}

Several halo-substituted alkoxypyridines were prepared and subjected to directed metalation and metalhalogen exchange reactions. The studies resulted in useful methods for synthesis of numerous substituted pyridines via regioselective lithiation, magnesation and halogen dance reactions.<smiles>COc1cc(Br)ncc1Br</smiles><smiles>COc1cc(Br)ncc1C=O</smiles><smiles>Brc1cnc(Br)c2c1OCOC2</smiles><smiles>Brc1cc2c(c(Br)n1)OCOC2</smiles>

Keywords: Alkoxypyridines, directed metalation, metal-halogen exchange, halogen dance reactions 


\section{Introduction}

Various alkoxypyridines are found in pharmaceutical agents, ${ }^{1-3}$ electronic materials, ${ }^{4}$ liquid crystals, ${ }^{5}$ organometallic complexes, ${ }^{6-8}$ and oligomers. ${ }^{9}$ They also have been used as synthetic building blocks for natural products and medicinal agents. ${ }^{10}$ Over the years, for use in our alkaloid total synthesis projects, ${ }^{11}$ several derivatives of alkoxypyridines have been prepared using directed metalation and metal-halogen exchange reactions. Reported herein are many examples that resulted from these efforts.

\section{Results and Discussion}

Much of our work in this area started with 4-methoxypyridine which is commercially available or can be easily made from 4-chloropyridine hydrochloride by nucleophilic substitution with sodium methoxide. Directed lithiation at the C-3 position can be carried out using mesityllithium (MesLi) ${ }^{12,13}$ or $\mathrm{PhLi}^{14}$ in THF to give good yields of products 1 on addition of electrophiles (Scheme 1).<smiles>COc1ccncc1</smiles>

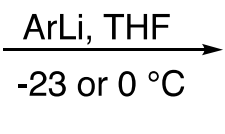<smiles>COc1ccncc1CCc1ccccc1</smiles>

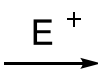<smiles>COc1ccncc1F</smiles>

Scheme 1. C-3 lithiation and substitution of 4-methoxypyridine.

Since bromo-substituted 4-methoxypyridines would likely be useful as precursors to other substituted pyridines, the directed lithiation of 2-bromo-4-methoxypyridine and 2,5-dibromopyridine was investigated as potential routes to these compounds. Conversion of 4-methoxypyridine to 2-bromo-4-methoxypyridine (2) was carried out using Fort's BuLi-LiDMAE base ${ }^{15}$ to lithiate the C-2 position followed by bromination with 1,2dibromotetrachloroethane (Scheme 2).<smiles>COc1ccncc1</smiles>

1) BuLi-LiDMAE

hexane, $-20^{\circ} \mathrm{C}, 1 \mathrm{~h}$<smiles>COc1ccnc([AlH2])c1</smiles>

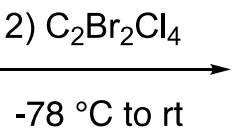
$62 \%$<smiles>COc1ccnc(Br)c1</smiles>

2

Scheme 2. C-2 lithiation and bromination of 4-methoxypyridine.

Treatment of the 2-bromo-4-methoxypyridine (2) with lithium tetramethylpiperidide (LTMP) followed by DMF yielded the aldehyde 3, which could subsequently be converted to alcohol $\mathbf{4}$ via sodium borohydride reduction with an overall yield of $70 \%$. The alcohol 4 was converted into dioxino[5,4-c]pyridine 5 in $72 \%$ yield using sodium iodide, paraformaldehyde and trimethylsilyl chloride in refluxing anhydrous acetonitrile 16 (Scheme 3). 


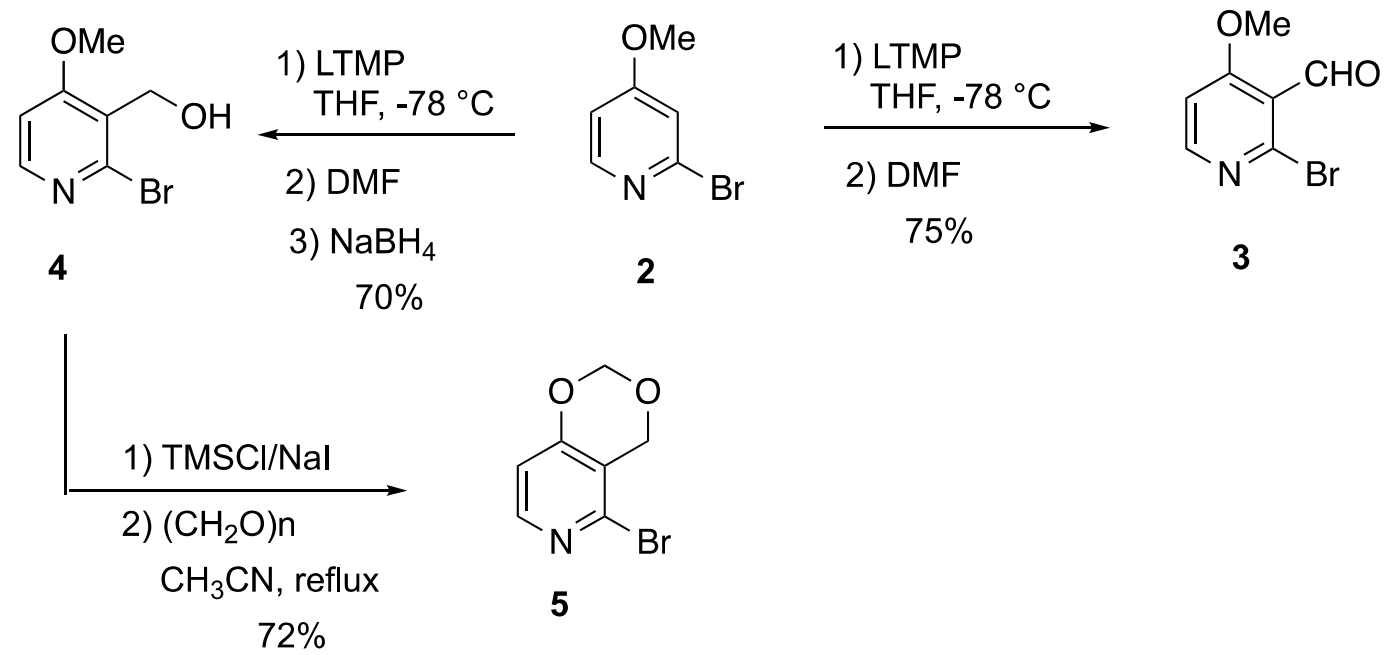

Scheme 3. C-3 lithiation and substitution of 2-bromo-4-methoxypyridine.

Next, conditions were developed for the regioselective C-4 lithiation/substitution of 2,5-dibromopyridine (6). Although C-4 lithiation seemed likely to occur, ${ }^{17}$ complications from subsequent pyridyne formation ${ }^{18}$ or halogen dance ${ }^{19}$ of the bromine atoms could be problematic. Fortunately, deprotonation with LDA at $-78{ }^{\circ} \mathrm{C}$ for $10 \mathrm{~min}$ gave $\mathbf{7}$ which on electrophile addition gave excellent yields of 4-substituted 2,5-dibromopyridines 8 . The assigned structure of the 4-iodo derivative 8 a was confirmed by X-ray crystallography. The 4-hydroxy derivative $8 \mathrm{e}$ was obtained in $94 \%$ yield by adding trimethylborate to 7 followed by peracetic acid (Scheme 4 ).<smiles>Brc1ccc(Br)nc1</smiles>

6

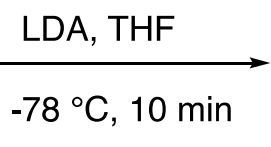

$-78^{\circ} \mathrm{C}, 10 \mathrm{~min}$

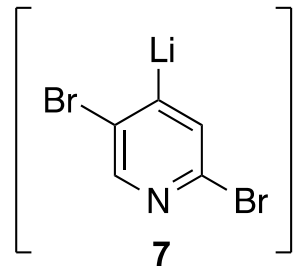<smiles>Fc1cc(Br)ncc1Br</smiles>

8 a-e

$E=I(8 a, 99 \%), M e(8 b, 86 \%)$,

TMS (8c, $89 \%)$, CHO (8d, $92 \%)$,

$\mathrm{OH}(8 \mathrm{e}, 94 \%)$

Scheme 4. Synthesis of 2,5-dibromopyridines 8 by C-4 lithiation and substitution of 6 .

Since a synthesis of 2,5-dibromo-4-methoxypyridine 9 was a goal, the conversion of iodide 8 a to 9 was investigated. When 8 a was treated with sodium methoxide and Cul $(10 \%)$ in refluxing methanol, the desired product 9 was obtained in $85 \%$ yield (Scheme 5 ).

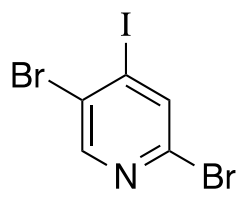

$8 a$

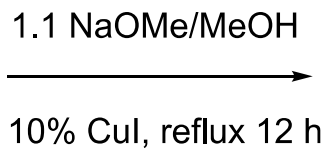

$85 \%$<smiles>COc1cc(Br)ncc1Br</smiles>

9

Scheme 5. Synthesis of 2,5-dibromo-4-methoxypyridine (9) from 8a. 
With compound 9 in hand, our next goal was the synthesis of alcohol 10 . We anticipated it could be accomplished from the methoxy-directed lithiation of 9, followed by trapping the lithiated pyridine with DMF, and then sodium borohydride reduction of the resulting aldehyde. Initial treatment of 9 with LTMP for 60 minutes prior to trapping with DMF generated the regioisomer $\mathbf{1 1}$ via a halogen dance mechanism. Reduction of $\mathbf{1 1}$ with sodium borohydride gave the corresponding alcohol 12. Fortunately, metalation of $\mathbf{9}$ with LDA for 5 minutes prior to addition of DMF provided the desired alcohol $\mathbf{1 0}$ on in situ reduction (Scheme 6). A mechanism study on the lithiation of 2-methoxypyridine with LDA vs LTMP has been reported by Fort and coworkers. ${ }^{20}$ The conversion of $\mathbf{1 0}$ to the [1,3]-dioxinopyridine $\mathbf{1 3}$ was carried out via a one-pot reaction ${ }^{16}$ in good yield (Scheme 6).<smiles>COc1c(Br)cnc(Br)c1CO</smiles>

10
1) LDA, $5 \mathrm{~min}$ $-78^{\circ} \mathrm{C}$

2) DMF

3) $\mathrm{NaBH}_{4}, \mathrm{MeOH}$ $70 \%$<smiles>COc1cc(Br)ncc1Br</smiles>

9

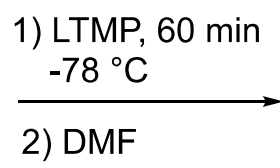

$70 \%$<smiles>COc1cc(Br)nc(Br)c1C=O</smiles>

11

$\mathrm{NaBH}_{4}$ $87 \%$<smiles>COc1cc(Br)nc(Br)c1CO</smiles>

12

13

Scheme 6. Synthesis of dibromopyridines 10-13 from 2,5-dibromo-4-methoxypyridine (9).

The regioselective lithiation and magnesation of 13 was examined. The [1,3]-dioxinopyridine 13 was treated with 1.0 equivalent of $n$-butyllithium at $-78{ }^{\circ} \mathrm{C}$ for $10 \mathrm{~min}$, and the resulting lithiopyridine was quenched with water. The ${ }^{1} \mathrm{H}$ NMR spectrum of the product was consistent with $\mathrm{C}-5$ lithiation to give compound 5. This regioselective lithiation is the same as that observed for 2,5-dibromopyridine; ${ }^{21}$ however, when 13 was treated with 1.2 equivalents of isopropylmagnesium chloride, the ${ }^{1} \mathrm{H}$ NMR spectra of the resulting product obtained from quenching with water indicated that $\mathbf{1 4}$ was the product. This regioselective C-2 magnesation is in sharp contrast with the observed C-5 magnesation of 2,5-dibromopyridine. ${ }^{22}$ Lithiumhalogen exchange at C-5 of $\mathbf{1 3}$ with $n$-butyllithium followed by addition of 2-chloroquinoline-3-carbaldehyde provided alcohol 15. Conversion of 15 to the bromide 16 was carried out using triphenylphosphine, 2,3dichloro-5,6-dicyano-1,4-benzoquinone (DDQ) and tetra- $n$-pentylammonium bromide in dichloromethane. ${ }^{23}$ Zinc modified cyanoborohydride reduction ${ }^{24}$ of compound $\mathbf{1 6}$ using zinc chloride and sodium cyanoborohydride in refluxing ether/THF provided compound 17 (Scheme 7). The assigned structure of compound 17 was confirmed by X-ray crystallography. 
<smiles>Brc1cncc2c1OCOC2</smiles>

14
1) $i-\mathrm{PrMgCl}, \mathrm{rt}$

THF

2) $\mathrm{H}_{2} \mathrm{O}$

$91 \%$<smiles>Brc1cnc(Br)c2c1OCOC2</smiles>

13
1) n-BuLi, $10 \mathrm{~min}$ $-78^{\circ} \mathrm{C}$

2) $\mathrm{H}_{2} \mathrm{O}$

$97 \%$<smiles>Brc1nccc2c1COCO2</smiles>

5
1) $n$-BuLi, THF

13 $-78^{\circ} \mathrm{C}$

2)<smiles>O=Cc1cc2ccccc2nc1Cl</smiles><smiles>OC(c1cc2ccccc2nc1Cl)c1cnc(Br)c2c1OCOC2</smiles>

$1553 \%$
1) $P P h_{3}, D D Q$

DCM, rt

2) (n-pentyl) ${ }_{4} \mathrm{NBr}$

$86 \%$<smiles>Clc1nc2ccccc2cc1C(Br)c1cnc(Br)c2c1OCOC2</smiles>

16

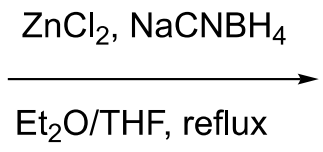

$63 \%$<smiles>Clc1nc2ccccc2cc1Cc1cnc(Br)c2c1OCOC2</smiles>

17

Scheme 7. Regioselective metalation of [1,3]-dioxinopyridine 13.

The metal-halogen exchange reactions of 2,5-dibromo-4-methoxypyridine (9) were also investigated. Treatment of $\mathbf{9}$ with $n$-BuLi followed by quenching of the lithiopyridine with water afforded 2 . It was observed that when the reaction between 9 and $n$-BuLi was allowed to proceed for 30 minutes prior trapping the lithiopyridine with DMF or ethyl formate, the aldehyde $\mathbf{3}$ was the observed product. In contrast, when a mixture consisting of $\mathbf{9}$ and ethyl formate was treated with $n$-BuLi, aldehyde $\mathbf{1 8}$ was generated. In addition, trapping the lithiopyridine with DMF within 5 minutes of reaction also resulted in $\mathbf{1 8}$. The formation of $\mathbf{3}$ from 9 must occur via a C-5 to C-3 lithium migration. A similar observation has been reported for other dibromopyridines. ${ }^{25}$ When 9 was treated with isopropylmagnesium chloride at room temperature, addition of 2-chloroquinoline-3-carbaldehyde gave a good yield of alcohol 19 (Scheme 8). 
<smiles>COc1ccnc(Br)c1</smiles>

2
1) n-BuLi, THF $-78^{\circ} \mathrm{C}, 30 \mathrm{~min}$

2) $\mathrm{H}_{2} \mathrm{O}$ $50 \%$<smiles>COc1cc(Br)ncc1Br</smiles>

9
1) n-BuLi, THF $-78^{\circ} \mathrm{C}, 30 \mathrm{~min}$

2) $\mathrm{DMF}$

$39 \% \%$<smiles>COc1ccnc(Br)c1C=O</smiles>

3<smiles>COc1cc(Br)ncc1C=O</smiles>

Scheme 8. Regioselective metalation/substitution of 2,5-dibromo-4-methoxypyridine (9).

Since iodopyridines can be precursors to alkoxypyridines, the metalation/substitution of 2,5-dibromo-4iodopyridine (8a) with LDA was investigated. Treatment of 8a with LDA (or LTMP) and DMF (or EtOCHO), followed by in situ reduction generated either alcohol $\mathbf{2 1}$ or $\mathbf{2 2}$ depending on how long lithiation was allowed to proceed prior to trapping with the formylating agent. If LDA is used and ethyl formate is added after only 5 minutes, the C-6 position is formylated leading to alcohol $\mathbf{2 1}$ after $\mathrm{NaBH}_{4}$ reduction. Using LTMP as base and increasing the lithiation time to 30 minutes provided the alcohol 22 as the product in good yield (Scheme 9). 


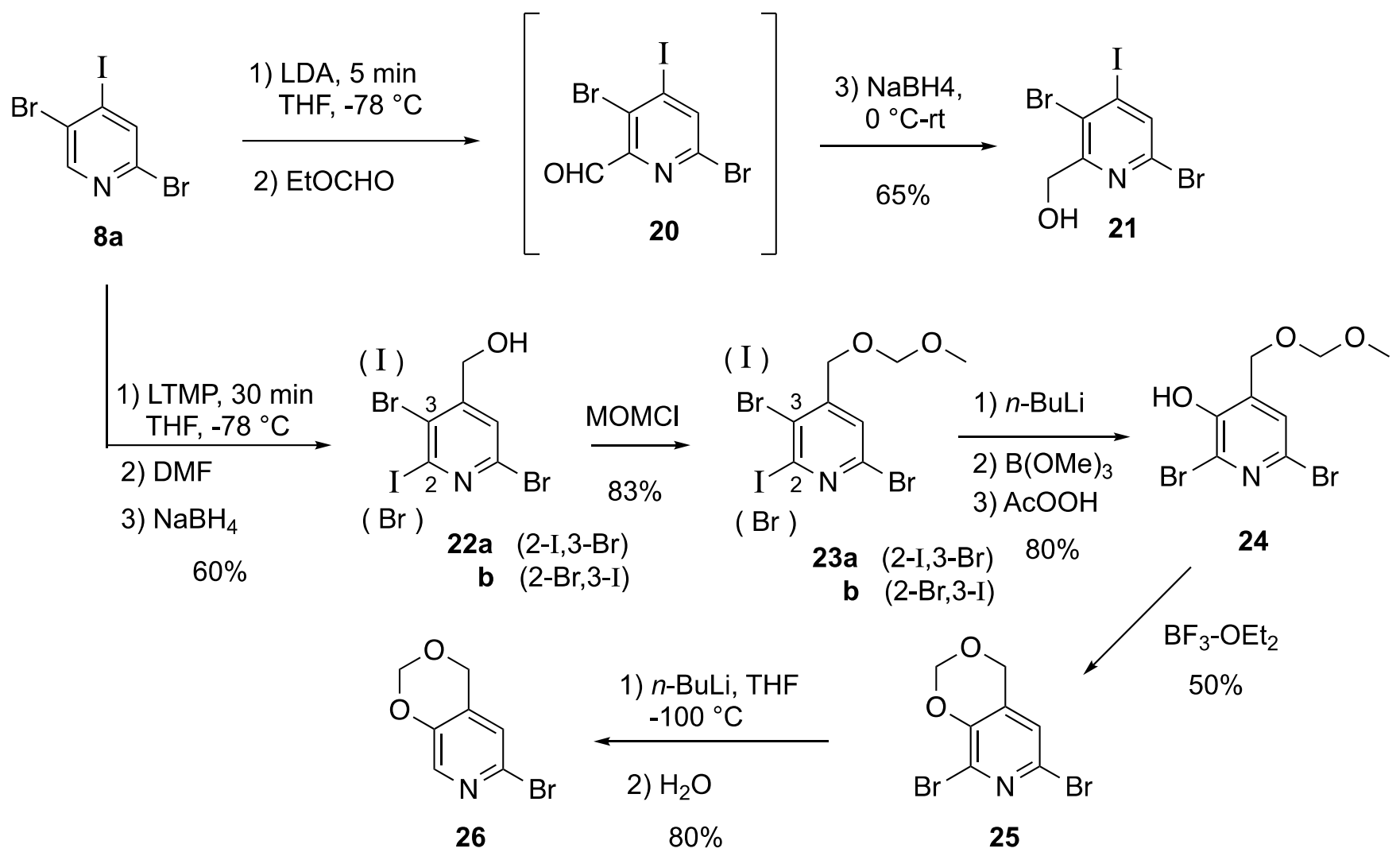

Scheme 9. Lithiation and halogen dance reactions of trihalopyridine 8 a.

Trihalopyridine $\mathbf{2 2}$ was protected as the MOM ether $\mathbf{2 3}$ and subjected to $n$-BuLi followed by addition of trimethylborate and oxidative workup to give pyridinol $\mathbf{2 4}$ in good yield. The assigned structure of 24 was confirmed by NMR and X-ray crystallography. As depicted in Scheme 9, the position of the iodine and bromine substituents at C-2 and C-3 of compounds $\mathbf{2 2}$ and $\mathbf{2 3}$ could not be determined conclusively. Either isomer of $\mathbf{2 3}$ could be a precursor to product 24 . Isomer 23 a could undergo lithium-iodine exchange at C-2 followed by a halogen-dance to give the C-3 pyridyllithium that leads to $24 .{ }^{26}$ Direct lithium-iodine exchange at $\mathrm{C}-3$ of $\mathbf{2 3 b}$ would give the same required intermediate. On treatment with $\mathrm{BF}_{3}$ etherate, $\mathbf{2 4}$ was converted to the dioxinopyridine 25. Regioselective lithium-halogen exchange occurs at C-2 of $\mathbf{2 5}$ with n-butyllithium in THF at low temperature to give 26 on quenching with water (Scheme 9).

\section{Conclusions}

The directed metalation and metal-halogen exchange reactions of various halo-substituted alkoxypyridines were found to be very regioselective. These and the halogen-dance transformations observed should be useful for the preparation of other numerous pyridine derivatives. During the course of these studies, several novel dioxinopyridines were prepared. These compounds have the potential to act as precursors to highly functionalized pyridines, pyridones, and pyridinols. 


\section{Experimental Section}

General. All reactions were performed in oven or flame-dried glassware under argon or nitrogen atmosphere and stirred magnetically. Tetrahydrofuran (THF), ether, and toluene were distilled from sodium/benzophenone ketyl prior to use. Triethylamine, diisopropylamine, diisopropylethylamine, $N, N^{\prime}$ dimethylethanolamine, 2,2,6,6- tetramethylpiperidine, ethyl formate, dimethylformamide, and benzene were distilled from calcium hydride and stored under argon over 4A molecular sieves. Other reagents and solvents from commercial sources were stored under argon and used directly. Melting points were obtained from a Thomas-Hoover capillary melting point apparatus and are uncorrected. Radial preparative layer chromatography (radial PLC) was performed using glass plates coated with 1, 2, or 4 mm layers of Kieselgel 60 PF254 containing gypsum. High-resolution mass spectral analysis (HRMS) was performed at North Carolina State University. X-ray spectral analysis was performed at North Carolina State University using Apex2 diffractometer. Elemental analyses were performed by Atlantic Microlab Inc. NMR spectra were obtained using a Varian Gemini GN-300 (300 MHz), Varian Mercury 300 (300 MHz), or Varian Mercury $400(400 \mathrm{MHz})$ spectrometer. Chemical shifts are in $\delta$ units (ppm) with TMS (0.00 ppm) used as an internal standard for ${ }^{1} \mathrm{H}$ $\mathrm{NMR}$ and $\mathrm{CDCl}_{3}$ absorption (77.23 ppm), $\mathrm{CD}_{3} \mathrm{OD}$ absorption (49.15 ppm), or $\mathrm{DMSOd}_{6}$ absorption (39.51 ppm) for ${ }^{13} \mathrm{C}$ NMR spectra. IR spectra were recorded on a Perkin-Elmer 1430 spectrometer.

4-Methoxy-2-bromopyridine (2). A solution of $N, N$-dimethylethanolamine $(1.40 \mathrm{~mL}, 13.93 \mathrm{mmol})$ in hexanes $(10 \mathrm{~mL})$ at $-20^{\circ} \mathrm{C}$ was treated with $n$-BuLi $(11.91 \mathrm{~mL}, 27.86 \mathrm{mmol}, 2.34 \mathrm{M}$ in hexanes). The reaction mixture was stirred under nitrogen for 30 minutes. Neat 4-methoxypyridine $(0.70 \mathrm{~mL}, 6.90 \mathrm{mmol})$ was added dropwise. The orange solution was stirred for one hour and then cooled to $-78{ }^{\circ} \mathrm{C}$. A solution of 1,2-dibromo-1,1,2,2tetrachloroethane $(5.40 \mathrm{~g}, 16.57 \mathrm{mmol})$ in THF $(5 \mathrm{~mL})$ was added dropwise, and the mixture was allowed to slowly warm to room temperature overnight. The reaction was quenched with water at $0{ }^{\circ} \mathrm{C}$ and extracted with diethyl ether. The combined extracts were dried over anhydrous magnesium sulfate and concentrated. The desired product was distilled $\left(70{ }^{\circ} \mathrm{C}, 3 \mathrm{mmHg}\right)$ to yield $0.81 \mathrm{~g}(62 \%)$ of 2 as yellow oil. ${ }^{1} \mathrm{H} \mathrm{NMR}(300 \mathrm{MHz}$, $\left.\mathrm{CDCl}_{3}\right) \delta 3.86(\mathrm{~s}, 3 \mathrm{H}), 6.78-6.80(\mathrm{dd}, J 2.1,2.4,5.9 \mathrm{~Hz}, 1 \mathrm{H}), 7.00-7.01$ (d, J 2.4 Hz, 1H), 8.16-8.18 (d, J $6.0 \mathrm{~Hz}, 1 \mathrm{H}$ ); ${ }^{13} \mathrm{C} \mathrm{NMR}\left(75 \mathrm{MHz}, \mathrm{CDCl}_{3}\right) \delta 55.6,110.2,113.2,143.0,150.6,166.8$; FTIR (film) 2321, 2350, 2371, 2851, 2925, $2956 \mathrm{~cm}^{-1}$; HRMS (FAB) calcd for $\mathrm{C}_{6} \mathrm{H}_{6} \mathrm{BrNO}(\mathrm{M}+1)$ 187.9711; found 187.9708 .

4-Methoxy-2-bromopyridine-3-carboxaldehyde (3). Method A. A solution of 2,2,6,6-tetramethylpiperidine $(0.60 \mathrm{~mL}, 3.56 \mathrm{mmol})$ in $3 \mathrm{~mL}$ of THF at $-20^{\circ} \mathrm{C}$ was treated dropwise with $n$-BuLi $(1.65 \mathrm{~mL}, 3.58 \mathrm{mmol}, 2.17 \mathrm{M}$ in hexanes). The mixture was stirred for 30 minutes under argon and then cooled to $-78{ }^{\circ} \mathrm{C}$. A solution of 2 $(0.598 \mathrm{~g}, 3.18 \mathrm{mmol})$ in THF $(5 \mathrm{~mL})$ was added dropwise. After stirring for 10 minutes, DMF $(0.32 \mathrm{~mL}, 4.13$ mmol) was added and stirring was continued for 30 minutes. Saturated sodium bicarbonate was added and the mixture was extracted with dichloromethane. The combined extracts were washed with brine, dried over anhydrous magnesium sulfate, and concentrated to give $0.593 \mathrm{~g}(86 \%)$ of crude 3 . The crude material was recrystallized from benzene/hexanes to give $0.517 \mathrm{~g}(75 \%)$ of 3 as white needles, mp $115-116{ }^{\circ} \mathrm{C} ;{ }^{1} \mathrm{H}$ NMR (300 $\left.\mathrm{MHz}, \mathrm{CDCl}_{3}\right) \delta 4.00(\mathrm{~s}, 3 \mathrm{H}), 6.93-6.95(\mathrm{~d}, J 6.0 \mathrm{~Hz}, 1 \mathrm{H}), 8.35-8.37$ (d, J $\left.6.0 \mathrm{~Hz}, 1 \mathrm{H}\right), 10.38(\mathrm{~s}, 1 \mathrm{H}) ;{ }^{13} \mathrm{C} \mathrm{NMR}(75$ $\mathrm{MHz}_{1} \mathrm{CDCl}_{3}$ ) $\delta$ 56.9, 107.7, 120.4, 145.4, 154.2, 167.5, 189.8; FTIR (film) 802, 829, 869, 1019, 1183, 1273, 1304, $1365,1433,1474,1544,1573,1700,2881,2919,2992 \mathrm{~cm}^{-1}$; HRMS (FAB) calcd for $\mathrm{C}_{7} \mathrm{H}_{6} \mathrm{BrNO} 2$ (M+1) 215.9660; found 215.9652 .

Method B. To a solution of $9(0.356 \mathrm{~g}, 1.33 \mathrm{mmol})$ in $3 \mathrm{~mL}$ THF at $-78{ }^{\circ} \mathrm{C}$ was added $n$-BuLi $(0.63 \mathrm{~mL}, 1.47$ $\mathrm{mmol})$ and the mixture was stirred under nitrogen for 30 minutes. DMF $(0.40 \mathrm{~mL}, 5.17 \mathrm{mmol})$ was added and the mixture was stirred for 30 minutes. Saturated sodium bicarbonate was added and the mixture was 
extracted with dichloromethane. The combined extracts were dried over anhydrous magnesium sulfate and concentrated. Purification by radial PLC (silica gel, EtOAc/hexane, 10:90) gave $0.113 \mathrm{~g}(39 \%)$ of 3 as a white solid. The ${ }^{1} \mathrm{H}$ NMR spectrum was identical to that obtained for 3 from method $A$ above.

(2-Bromo-4-methoxypyridin-3-yl)methanol (4). To a solution of 2,2,6,6-tetramethylpiperidine (2.30 mL, 13.63 $\mathrm{mmol}$ ) in $5 \mathrm{~mL}$ of THF at $-20{ }^{\circ} \mathrm{C}$ was added $n$-BuLi $(6.40 \mathrm{~mL}, 13.44 \mathrm{mmol}, 2.10 \mathrm{M}$ in hexanes). The mixture was stirred for 30 minutes under argon and then cooled to $-78^{\circ} \mathrm{C}$. A solution of 2 ( $\left.2.27 \mathrm{~g}, 12.07 \mathrm{mmol}\right)$ in THF (10 $\mathrm{mL}$ ) was added dropwise. After stirring for 10 minutes, DMF ( $3 \mathrm{~mL}, 38.7 \mathrm{mmol})$ was added and the mixture was stirred for 30 minutes. Saturated sodium bicarbonate was added, and the aqueous mixture was extracted with dichloromethane. The combined extracts were washed with brine, dried over anhydrous magnesium sulfate, and concentrated. The residue was dissolved in dichloromethane/ethanol (50 mL/50 mL). Sodium borohydride $(0.457 \mathrm{~g}, 12.08 \mathrm{mmol})$ was added and the mixture was stirred for 30 minutes at room temperature. Water was added, and the mixture was extracted with dichloromethane. The combined extracts were washed with brine and dried over anhydrous magnesium sulfate. Concentration and purification by radial PLC (silica gel, EtOAc/hexane, 50:50) yielded $1.85 \mathrm{~g}(70 \%)$ of 4 as a white solid, mp $138-141{ }^{\circ} \mathrm{C} ;{ }^{1} \mathrm{H}$ NMR $\left(400 \mathrm{MHz}, \mathrm{CDCl}_{3}\right)$ ठ 2.39-2.42 (t, J 6.8, $\left.6.4 \mathrm{~Hz}, 1 \mathrm{H}\right), 3.93(\mathrm{~s}, 3 \mathrm{H}), 4.83-4.85$ (d, J $\left.6.8 \mathrm{~Hz}, 2 \mathrm{H}\right), 6.81-2.82(\mathrm{~d}, J 5.2 \mathrm{~Hz}$, $1 \mathrm{H}), 8.20-8.21$ (d, J $5.2 \mathrm{~Hz}, 1 \mathrm{H}) ;{ }^{13} \mathrm{C} N M R\left(75 \mathrm{MHz}, \mathrm{CDCl}_{3}\right) \delta 56.4,59.4,106.7,125.3,145.1,150.9,165.4 ;$ FTIR (film) 822, 840, 1015, 1293, 1580, 2321, 2371, 2848, 2952, $3271 \mathrm{~cm}^{-1}$; HRMS (FAB) calcd for $\mathrm{C}_{7} \mathrm{H}_{8} \mathrm{BrNO}_{2}(\mathrm{M}+1)$ 217.9817; found 217.9809.

5-Bromo-4H-[1,3]dioxino[5,4-c]pyridine (5). Method A. To a mixture containing 4 (0.49 g, 2.25 mmol), sodium iodide $(0.337 \mathrm{~g}, 2.25 \mathrm{mmol})$, and paraformaldehyde $(2.0 \mathrm{~g})$ in $40 \mathrm{~mL}$ of anhydrous acetonitrile was added trimethylsilyl chloride $(1 \mathrm{~mL}, 7.9 \mathrm{mmol})$. The mixture was heated at reflux for one hour and then cooled to room temperature. Saturated sodium bicarbonate $(25 \mathrm{~mL})$ was added and the mixture was extracted with ether. The combined extracts were washed with $10 \%$ sodium thiosulfate and brine, and dried over anhydrous magnesium sulfate. Concentration and purification by radial PLC (silica gel, EtOAc/hexane, 10:90) yielded 0.35 $\mathrm{g}(72 \%)$ of 5 as a white solid, $\mathrm{mp} 52-54{ }^{\circ} \mathrm{C} ;{ }^{1} \mathrm{H}$ NMR $\left(400 \mathrm{MHz}, \mathrm{CDCl}_{3}\right) \delta 4.78(\mathrm{~s}, 2 \mathrm{H}), 5.28(\mathrm{~s}, 2 \mathrm{H}), 6.79-6.81$ (d, J $6.0 \mathrm{~Hz}, 1 \mathrm{H}), 8.11-8.12(\mathrm{~d}, J 5.6 \mathrm{~Hz}, 1 \mathrm{H}) ;{ }^{13} \mathrm{C} \mathrm{NMR}\left(100 \mathrm{MHz}, \mathrm{CDCl}_{3}\right) \delta 66.0,91.8,112.4,118.6,140.1,149.4$, 161.0; FTIR (film) 874, 952, 973, 1279, 1560, 1593, 2321, 2369, 2853, 2896, $2959 \mathrm{~cm}^{-1}$; HRMS (FAB) calcd for $\mathrm{C}_{7} \mathrm{H}_{6} \mathrm{BrNO}_{2}(\mathrm{M}+1)$ 215.9655; found 215.9662 .

Method B. To a solution of $13(15 \mathrm{mg}, 0.05 \mathrm{mmol})$ in THF $(0.50 \mathrm{~mL})$ at $-78{ }^{\circ} \mathrm{C}$ was added $n$-BuLi $(25 \mu \mathrm{L}, 0.05$ $\mathrm{mmol}, 2.05 \mathrm{M}$ in hexanes). The mixture was stirred for 10 minutes under nitrogen. Water was added and the aqueous mixture was extracted with dichloromethane. The combined extracts were washed with brine, dried over anhydrous magnesium sulfate, and concentrated to yield $10.66 \mathrm{mg}(97 \%)$ of 5 as a white solid. The ${ }^{1} \mathrm{H}$ NMR data was consistent with structure 5 obtained from method $A$ above.

2,5-Dibromo-4-iodopyridine (8a). To LDA (7.85 mmol) in THF $(5 \mathrm{~mL})$ at $-78^{\circ} \mathrm{C}$ was added $6(1.59 \mathrm{~g}, 6.33 \mathrm{mmol})$ in THF $(5 \mathrm{~mL})$ dropwise, and the reaction mixture was stirred for 10 minutes. lodine $(4.82 \mathrm{~g}, 18.99 \mathrm{mmol})$ in THF (10 mL) was added dropwise, and the mixture was stirred for 30 minutes. Saturated sodium bicarbonate was added and the mixture was extracted with ether. The combined extracts were washed with $10 \%$ sodium thiosulfate and brine, and dried over anhydrous magnesium sulfate. Concentration and purification by radial PLC (silica gel, EtOAc/hexane, 2:98) yielded $2.25 \mathrm{~g}(98 \%)$ of $8 \mathrm{a}$ as a white solid, $\mathrm{mp} 136-138{ }^{\circ} \mathrm{C} ;{ }^{1} \mathrm{H}$ NMR (400 $\left.\mathrm{MHz} \mathrm{CDCl}_{3}\right) \delta 8.01(\mathrm{~s}, 1 \mathrm{H}), 8.46(\mathrm{~s}, 1 \mathrm{H}) ;{ }^{13} \mathrm{C} \mathrm{NMR}\left(100 \mathrm{MHz}, \mathrm{CDCl}_{3}\right) \delta 114.4,128.4,138.6,140.1,150.6 ; \mathrm{FTIR}$ (film) 659, 765, 867, 1012, 1101, 1268, 1293, 1412, 1430, 1528, 2341, 2361, 3061, $3083 \mathrm{~cm}^{-1}$; HRMS (FAB) calcd for $\mathrm{C}_{5} \mathrm{H}_{2} \mathrm{Br} 2 \mathrm{IN}(\mathrm{M}+1) 361.7677$; found 361.7697 . Structure confirmed by X-ray crystallography.

2,5-Dibromo-4-picoline (8b). The procedure for $\mathbf{8 a}$ was applied to $\mathbf{8 b}$ using methyl iodide $(0.40 \mathrm{~mL}, 6.48$ $\mathrm{mmol}$ ) as the electrophile. Purification by radial PLC (silica gel, Hexanes, EtOAc/Hexanes, 5:95) yielded $0.559 \mathrm{~g}$ 
(86\%) of $8 \mathrm{~b}$ as a yellow oil; ${ }^{1} \mathrm{H}$ NMR $\left(300 \mathrm{MHz}, \mathrm{CDCl}_{3}\right) \delta 2.38(\mathrm{~s}, 3 \mathrm{H}), .37(\mathrm{~s}, 1 \mathrm{H}), 8.40(\mathrm{~s}, 1 \mathrm{H}) ;{ }^{13} \mathrm{C} \mathrm{NMR}(75 \mathrm{MHz}$, $\left.\mathrm{CDCl}_{3}\right) \delta 22.3,123.0,129.9,140.7,150.0,151.4$; HRMS (FAB) calcd for $\mathrm{C}_{6} \mathrm{H}_{5} \mathrm{Br}_{2} \mathrm{~N}(\mathrm{M}+\mathrm{H})$ 249.8863; found 249.8861.

2,5-Dibromo-4-trimethylsilanylpyridine (8c). The procedure for $\mathbf{8 a}$ was applied to $\mathbf{8 c}$ using chlorotrimethylsilane $(1 \mathrm{~mL}, 7.88 \mathrm{mmol}$ ) as the electrophile. Purification by radial PLC (silica gel, Hexanes, EtOAc/hexanes, 5:95) gave $0.713 \mathrm{~g}(89 \%)$ of $8 \mathrm{c}$ as a yellow solid, $\mathrm{mp} 59-62{ }^{\circ} \mathrm{C} ;{ }^{1} \mathrm{H} \mathrm{NMR}\left(400 \mathrm{MHz}, \mathrm{CDCl}_{3}\right) \delta 0.42$ (s, 9H), 7.45 (s, 1H), 8.39 (s, 1H); ${ }^{13} \mathrm{C}$ NMR (100 MHz, CDCl 3 ) $\delta-1.3,127.4,134.5,141.0,151.6,154.8$; FTIR (film) 844, 1013, 1093, 1249, 1422, 1489, 1548, 2898, $2960 \mathrm{~cm}^{-1}$; HRMS (FAB) calcd for $\mathrm{C}_{8} \mathrm{H}_{11} \mathrm{Br}_{2} \mathrm{NSi}(\mathrm{M}+\mathrm{H}) 307.9098$; found 307.9100 .

2,5-Dibromopyridine-4-carboxaldehyde (8d). To LDA (3.14 mmol) in THF (3 mL) at $-78{ }^{\circ} \mathrm{C}$ was added 6 (0.614 g, $2.59 \mathrm{mmol})$ in THF $(2 \mathrm{~mL})$ dropwise, and the mixture stirred for 10 minutes. Ethyl formate $(0.45 \mathrm{~mL}, 5.57$ mmol) was added dropwise and stirring was continued for 30 minutes. Saturated sodium bicarbonate was added and the mixture was extracted with dichloromethane. The combined extracts were washed with brine and dried over anhydrous magnesium sulfate. Concentration and purification by radial PLC (silica gel, EtOAc/hexane, 5:95) yielded $0.632 \mathrm{~g}(92 \%)$ of $8 \mathrm{~d}$ as a yellow solid, $\mathrm{mp} 62-65{ }^{\circ} \mathrm{C} ;{ }^{1} \mathrm{H} \mathrm{NMR}(400 \mathrm{MHz}, \mathrm{CDCl}) \delta$ 7.86 (s, 1H), 8.66 (s, 1H), $\left.10.29(\mathrm{~s}, 1 \mathrm{H}) ;{ }^{13} \mathrm{C} \mathrm{NMR} \mathrm{(100} \mathrm{MHz,} \mathrm{CDCl} 3\right) \delta 121.7,127.2,140.5,141.8,154.0,189.2$; FTIR (film) 1094, 1171, 1316, 1426, 1692, 2295, 2360, 2921, $3067 \mathrm{~cm}^{-1}$; HRMS (FAB) calcd for $\mathrm{C}_{6} \mathrm{H}_{3} \mathrm{Br}_{2} \mathrm{NO}$ (M+MeOH) 295.8916; found 295.8916.

2,5-Dibromo-4-hydroxypyridine (8e). To LDA (3.56 mmol) in THF (3 mL) at -78 ${ }^{\circ} \mathrm{C}$ was added 6 (0.703 g, 2.97 $\mathrm{mmol})$ in THF $(2 \mathrm{~mL})$ dropwise, and the mixture was stirred for 10 minutes. Trimethylborate $(0.70 \mathrm{~mL}, 6.28$ $\mathrm{mmol}$ ) was added dropwise and the stirring continued for two hours. Peracetic acid (1.55 mL, $6.52 \mathrm{mmol}, 32 \%$ in acetic acid) was added dropwise, and the mixture was allowed to slowly warm up to room temperature overnight. After cooling to $-20{ }^{\circ} \mathrm{C}, 10 \%$ sodium thiosulfate was added. The mixture was allowed to warm to room temperature and then extracted with dichloromethane. The combined extracts were filtered through a pad of anhydrous magnesium sulfate and concentrated. Purification by column chromatography (silica, EtOAc) yielded $0.705 \mathrm{~g}(94 \%)$ of $8 \mathrm{e}$ as a pale yellow solid, $\mathrm{mp} 201-203{ }^{\circ} \mathrm{C} ;{ }^{1} \mathrm{H} \mathrm{NMR}(400 \mathrm{MHz}, \mathrm{DMSOd}) \delta 7.05(\mathrm{~s}, 1 \mathrm{H})$, $8.33(\mathrm{~s}, 1 \mathrm{H}), 12.28(\mathrm{~s}, 1 \mathrm{H}) ;{ }^{13} \mathrm{C}$ NMR $\left(100 \mathrm{MHz}, \mathrm{DMSOd}_{6}\right) \delta 109.2,115.2,140.3,151.6,162.5 ; \mathrm{FTIR}(\mathrm{KBr}) 547$, $571,711,846,906,1028,1043,1084,1232,1286,1366,1414,1506,1568,1609,1853,2542,2843,3084$, $3428 \mathrm{~cm}^{-1}$; HRMS (FAB) calcd for $\mathrm{C}_{5} \mathrm{H}_{3} \mathrm{Br}_{2} \mathrm{NO}(\mathrm{M}+\mathrm{H})$ 251.8660; found 251.8666 .

2,5-Dibromo-4-methoxypyridine (9). A mixture containing 8a (3.31 g, $9.12 \mathrm{mmol}$ ), copper iodide (0.17 g, 0.91 $\mathrm{mmol})$, and sodium methoxide ( $0.23 \mathrm{~g}$ sodium, $10.04 \mathrm{mmol}$ in $50 \mathrm{~mL}$ anhydrous methanol) was heated at reflux overnight. Saturated sodium bicarbonate was added and the mixture was filtered through a pad of Celite. The pad was washed with dichloromethane and then the aqueous filtrate was extracted with dichloromethane. The combined extracts were washed with brine and dried over anhydrous magnesium sulfate. Concentration and purification by radial PLC (silica gel, EtOAc/hexanes, 2:98) yielded $2.07 \mathrm{~g}(85 \%)$ of 9 as a white solid, $\mathrm{mp} 124-125{ }^{\circ} \mathrm{C} ;{ }^{1} \mathrm{H}$ NMR $\left(300 \mathrm{MHz}, \mathrm{CDCl}_{3}\right) \delta 3.96(\mathrm{~s}, 3 \mathrm{H}), 6.99(\mathrm{~s}, 1 \mathrm{H}), 8.33(\mathrm{~s}, 1 \mathrm{H}) ;{ }^{13} \mathrm{C} \mathrm{NMR}(75$ $\mathrm{MHz}_{1} \mathrm{CDCl}_{3}$ ) $\delta 56.8,110.4,111.8,1419,151.8,163.1$; FTIR (film) 847, 921, 1014, 1100, 1153, 1269, 1295, 1337, 1477, 1540, 1564, 1698, 1775, 2340, 2361, 2850, 2923, 2990, $3080 \mathrm{~cm}^{-1}$; HRMS (FAB) calcd for $\mathrm{C}_{6} \mathrm{H}_{5} \mathrm{Br}_{2} \mathrm{NO}$ $(M+1) 265.8816$; found 265.8835 .

(2,5-Dibromo-4-methoxypyridin-3-yl)methanol (10). To a solution of diisopropylamine $(0.24 \mathrm{~mL}, 1.71 \mathrm{mmol})$ in THF $(5 \mathrm{~mL})$ at $-20{ }^{\circ} \mathrm{C}$ was added $n$-BuLi $(0.73 \mathrm{~mL}, 1.72 \mathrm{mmol}, 2.36 \mathrm{M}$ in hexanes). The mixture was stirred for one hour under nitrogen and then cooled to $-78{ }^{\circ} \mathrm{C}$. A solution of 9 ( $\left.0.376 \mathrm{~g}, 1.40 \mathrm{mmol}\right)$ in THF (5 mL) was added dropwise and the mixture was stirred for 5 minutes. DMF $(0.35 \mathrm{~mL}, 4.52 \mathrm{mmol})$ was added and stirring was continued for 30 minutes. Methanol $(5 \mathrm{~mL})$ and $\mathrm{NaBH}_{4}(0.2 \mathrm{~g}, 5.29 \mathrm{mmol})$ were added. The cooling bath 
was removed, stirring was continued at room temperature for 15 minutes, and the mixture was extracted with dichloromethane. The combined extracts were washed with saturated sodium bicarbonate and dried over anhydrous magnesium sulfate. Concentration and purification by radial PLC (silica gel, EtOAc/hexanes, 5:95, $10: 90)$ yielded $0.293 \mathrm{~g}(70 \%)$ of 10 as a yellow solid, $\mathrm{mp} 94-96{ }^{\circ} \mathrm{C} ;{ }^{1} \mathrm{H}$ NMR $\left(400 \mathrm{MHz}, \mathrm{CDCl}_{3}\right) \delta 2.24-2.27(\mathrm{t}, 1 \mathrm{H}$, J 6.8, $6.4 \mathrm{~Hz}), 4.04(\mathrm{~s}, 3 \mathrm{H}), 4.83-4.85(\mathrm{~d}, 2 \mathrm{H}, J 6.4 \mathrm{~Hz}), 8.43(\mathrm{~s}, 1 \mathrm{H}) ;{ }^{13} \mathrm{C} \mathrm{NMR}\left(100 \mathrm{MHz}, \mathrm{CDCl}_{3}\right) \delta 59.7,62.9$, 115.6, 132.6, 144.1, 152.5, 164.3; FTIR (film) 833, 1007, 1149, 1262, 1362, 1409, 1458, 1550, 1691, 1819, 2296, 2390, 2850, 2944, $3385 \mathrm{~cm}^{-1}$; HRMS (FAB) calcd for $\mathrm{C}_{7} \mathrm{H}_{7} \mathrm{Br}_{2} \mathrm{NO}_{2}(\mathrm{M}+1)$ 296.8922; found 296.8906. Structure was confirmed by X-ray crystallography.

2,6-Dibromo-4-methoxypyridine-3-carboxaldehyde (11). To a solution of 2,2,6,6-tetramethylpiperidine $(0.35$ $\mathrm{mL}, 2.07 \mathrm{mmol})$ in THF $(1 \mathrm{~mL})$ at $-20^{\circ} \mathrm{C}$ was added $n$-BuLi $(1.04 \mathrm{~mL}, 2.08 \mathrm{mmol}, 2.0 \mathrm{M}$ in hexanes). The mixture was stirred for 30 minutes under argon and then cooled to $-78^{\circ} \mathrm{C}$. A solution of $9(0.46 \mathrm{~g}, 1.72 \mathrm{mmol})$ in THF (2 $\mathrm{mL}$ ) was added dropwise and stirring was continued for one hour. DMF $(0.35 \mathrm{~mL}, 4.52 \mathrm{mmol})$ was added dropwise and the mixture was stirred for 30 minutes. Saturated sodium bicarbonate was added, and the mixture was extracted with ethyl acetate. The combined extracts were washed with brine and dried over anhydrous magnesium sulfate. Concentration and purification by radial PLC (silica gel, EtOAc/hexanes, 10:90) yielded $0.36 \mathrm{~g}(70 \%)$ of 11 as a yellow solid, mp 118-120 ${ }^{\circ} \mathrm{C} ;{ }^{1} \mathrm{H} \mathrm{NMR}\left(300 \mathrm{MHz}^{\mathrm{CDCl}}\right)_{3} \delta 3.99$ (s, $\left.3 \mathrm{H}\right), 7.12$ (s, 1H), 10.27 (s, 1H); ${ }^{13} \mathrm{C} \mathrm{NMR} \mathrm{(75} \mathrm{MHz,} \mathrm{CDCl} 3$ ) $\delta 57.3,111.8,119.6,143.8,145.6,167.7,188.7$; FTIR (film) 896, 1096, 1422, 1560, 1702, 2306, 2685, 2987, $3054 \mathrm{~cm}^{-1}$; HRMS (FAB) calcd for $\mathrm{C}_{7} \mathrm{H}_{5} \mathrm{Br}_{2} \mathrm{NO}_{2}(\mathrm{M}+1)$ 294.8765; found 294.8737.

(2,6-Dibromo-4-methoxypyridin-3-yl)methanol (12). To a solution of $11(0.40 \mathrm{~g}, 1.36 \mathrm{mmol})$ in dichloromethane/ethanol $(1: 1,10 \mathrm{~mL})$ at room temperature was added sodium borohydride $(0.102 \mathrm{~g}, 2.70$ $\mathrm{mmol})$. The mixture was stirred for 10 minutes. Water $(20 \mathrm{~mL})$ was added and the aqueous mixture was extracted with ethyl acetate. The combined extracts were washed with brine, dried over anhydrous magnesium sulfate, and concentrated to yield $0.35 \mathrm{~g}(87 \%)$ of 12 as a yellow solid, mp $97-99{ }^{\circ} \mathrm{C} ;{ }^{1} \mathrm{H}$ NMR (400 $\mathrm{MHz}_{\mathrm{CDCl}}$ ) $\delta$ 2.12-2.15 (t, $1 \mathrm{H}$, J 6.8, $\left.6.4 \mathrm{~Hz}\right), 3.95$ (s, 3H), 4.78-4.80 (d, 2H, J $\left.6.0 \mathrm{~Hz}\right), 7.00(\mathrm{~s}, 1 \mathrm{H}) ;{ }^{13} \mathrm{C} \mathrm{NMR}(100$ $\mathrm{MHz}_{\mathrm{CDCl}}$ ) $\delta 56.9,59.1,110.8,125.0,141.1,143.2,166.0 ;$ FTIR (film) 876, 1038, 1099, 1287, 1347, 1420, 1462, 1570, 2851, 2890, 2946, $3311 \mathrm{~cm}^{-1}$; HRMS (FAB) calcd for $\mathrm{C}_{7} \mathrm{H}_{7} \mathrm{Br}_{2} \mathrm{NO}_{2}$ (M+1) 296.8922; found 296.8906. Structure was confirmed by X-ray crystallography.

5,8-Dibromo-4H-[1,3]dioxino[5,4-c]pyridine (13). To a mixture containing 10 (1.236 g, $4.16 \mathrm{mmol}$ ), sodium iodide $(0.624 \mathrm{~g}, 4.16 \mathrm{mmol})$, and paraformaldehyde $(2.58 \mathrm{~g})$ in anhydrous acetonitrile $(150 \mathrm{~mL}) \mathrm{was}$ added trimethylsilyl chloride $(3.2 \mathrm{~mL}, 25.2 \mathrm{mmol})$. The mixture was heated at reflux overnight and then cooled to room temperature. Aqueous 5\% sodium hydroxide was added, and the mixture was extracted with dichloromethane. The combined extracts were washed with $10 \%$ sodium thiosulfate and brine. Concentration and purification by radial PLC (silica gel, EtOAc/hexanes, 5:95) yielded $0.960 \mathrm{~g}(75 \%)$ of 13 as a white solid, $\mathrm{mp}$ $118-120{ }^{\circ} \mathrm{C} ;{ }^{1} \mathrm{H}$ NMR $\left(400 \mathrm{MHz}, \mathrm{CDCl}_{3}\right) \delta 4.83(\mathrm{~s}, 2 \mathrm{H}), 5.39(\mathrm{~s}, 2 \mathrm{H}), 8.31(\mathrm{~s}, 1 \mathrm{H}) ;{ }^{13} \mathrm{C} \mathrm{NMR}\left(75 \mathrm{MHz}, \mathrm{CDCl}_{3}\right) \delta 64.1$, 92.5, 108.3, 117.2, 146.8, 150.0 157.9; FTIR (film) 740, 955, 1086, 1135, 1211, 1270, 1345, 1406, 1455, 1536, 1574, 2851, $2915 \mathrm{~cm}^{-1}$; HRMS (FAB) calcd for $\mathrm{C}_{7} \mathrm{H}_{5} \mathrm{Br}_{2} \mathrm{NO}_{2}(\mathrm{M}+1)$ 293.8759; found 293.8759.

8-Bromo-4H-[1,3]dioxino[5,4-c]pyridine (14). To a solution of 13 (30 mg, $0.10 \mathrm{mmol}$ ) in THF (0.50 mL) was added isopropylmagnesium chloride $(70 \mu \mathrm{L}, 0.12 \mathrm{mmol}, 1.75 \mathrm{M}$ in THF). The mixture was stirred at room temperature for 30 minutes under nitrogen. Saturated ammonium chloride was added and the mixture was extracted with dichloromethane. The combined extracts were dried over anhydrous magnesium sulfate and concentrated to yield $20 \mathrm{mg}(91 \%)$ of 14 as a white solid, mp 104- $106{ }^{\circ} \mathrm{C} ;{ }^{1} \mathrm{H} \mathrm{NMR}\left(400 \mathrm{MHz}, \mathrm{CDCl}_{3}\right) \delta 4.92(\mathrm{~s}$, $2 \mathrm{H}), 5.42(\mathrm{~s}, 2 \mathrm{H}), 8.11(\mathrm{~s}, 1 \mathrm{H}), 8.50(\mathrm{~s}, 1 \mathrm{H}) ;{ }^{13} \mathrm{C} \mathrm{NMR}\left(100 \mathrm{MHz}, \mathrm{CDCl}_{3}\right) \delta 64.3,97.8,109.0,118.9,145.6,151.5$, 
155.9; FTIR (film) 740, 891, 953, 1085, 1126, 1265, 1470, 1557, 1592, 1723, 2855, 2922, $2957 \mathrm{~cm}^{-1}$; HRMS (FAB) calcd for $\mathrm{C}_{7} \mathrm{H}_{6} \mathrm{BrNO}_{2}(\mathrm{M}+1) 215.9655$; found 215.9654 .

(5-Bromo-4H-[1,3]dioxino[5,4-c]pyridine-8-yl)-(2-chloroquinolin-3-yl)-methanol (15). To a solution of 13 $(0.366 \mathrm{~g}, 1.24 \mathrm{mmol})$ in THF $(1.0 \mathrm{~mL})$ at $-78^{\circ} \mathrm{C}$ was added with $n$-BuLi $(0.75 \mathrm{~mL}, 1.51 \mathrm{mmol}, 2.01 \mathrm{M}$ in hexanes), and the mixture was stirred for 5 minutes under nitrogen. A solution of 2-chloroquinoline-3-carbaldehyde $(0.285 \mathrm{~g}, 1.49 \mathrm{mmol})$ in THF $(5 \mathrm{~mL})$ was added dropwise and stirring was continued for one hour. Saturated ammonium chloride was added and the aqueous mixture was extracted with dichloromethane. The combined extracts were dried over anhydrous magnesium sulfate and concentrated. Purification by radial PLC (silica gel, EtOAc/hexanes, 10:90, 30:70) yielded $0.268 \mathrm{~g}(53 \%)$ of 15 as a yellow solid, mp 186-188 ${ }^{\circ} \mathrm{C} ;{ }^{1} \mathrm{H} \mathrm{NMR}(400 \mathrm{MHz}$, $\left.\mathrm{CDCl}_{3}\right) \delta 4.78(\mathrm{~s}, 2 \mathrm{H}$ ), 5.36-5.40 (ABquartet, J 18.4, 7.6 Hz, 2H), 6.19-6.20 (d, J 4.4 Hz, 1H), 6.45-6.47 (d, J $4.4 \mathrm{~Hz}$, $1 \mathrm{H}), 7.64-7.68(\mathrm{t}, J 7.2,7.2 \mathrm{~Hz}, 1 \mathrm{H}), 7.80-7.84(\mathrm{t}, J$ 8.0, 7.2 Hz, 1H), 7.94-7.97 (d, J 8.4 Hz, 1H), $8.05(\mathrm{~s}, 1 \mathrm{H}), 8.11-$ $8.13(\mathrm{~d}, J 8.0 \mathrm{~Hz}, 1 \mathrm{H}), 8.54(\mathrm{~s}, 1 \mathrm{H}) ;{ }^{13} \mathrm{C} N M R\left(100 \mathrm{MHz}, \mathrm{CDCl}_{3}\right) \delta 64.0,64.9,91.6,117.9,125.9,127.0,127.5$, 128.4, 130.8, 134.4, 137.4, 138.5, 146.4, 147.1, 147.7, 148.7, 158.1; FTIR (film) 882, 955, 1036, 1073, 1156, $1244,1407,1459,1584,1686,2848,2891,3216 \mathrm{~cm}^{-1}$; HRMS (FAB) calcd for $\mathrm{C}_{17} \mathrm{H}_{12} \mathrm{BrClN}_{2} \mathrm{O}_{3}(\mathrm{M}+1)$ 406.9797; found 406.9792.

5-Bromo-8-[bromo-(2-chloroquinolin-3-yl)-methyl]-4H-[1,3]dioxino[5,4-c]pyridine

(16).

Tetra-npentylammonium bromide (56 mg, $0.15 \mathrm{mmol}$ ) was added to a mixture containing triphenylphosphine (39 $\mathrm{mg}$, $0.15 \mathrm{mmol}$ ) and 2,3-dichloro-5,6-dicyano-1,4- benzoquinone (33 $\mathrm{mg}, 0.15 \mathrm{mmol})$ in anhydrous dichloromethane $(5 \mathrm{~mL})$. The mixture was stirred for one hour under nitrogen. A solution of 15 (30 mg, 0.07 $\mathrm{mmol})$ THF ( $1 \mathrm{~mL}$ ) was added dropwise and stirring continued at room temperature overnight. Concentration and purification by radial PLC (silica gel, EtOAc/hexanes, 10:90, 30:70) yielded $30 \mathrm{mg}(86 \%)$ of 16 as a white solid. ${ }^{1} \mathrm{H}$ NMR $\left(400 \mathrm{MHz}^{\mathrm{CDCl}}{ }_{3}\right) \delta 4.79(\mathrm{~s}, 2 \mathrm{H}), 5.32-5.38$ (ABquartet, J 25.6, $\left.14.4 \mathrm{~Hz}, 2 \mathrm{H}\right), 6 . .78(\mathrm{~s}, 1 \mathrm{H}), 7.60$ $7.64(\mathrm{t}, \mathrm{J} 6.8,8.0 \mathrm{~Hz}, 1 \mathrm{H}), 7.76-7.80(\mathrm{t}, \mathrm{J} 8.0,7.6 \mathrm{~Hz}, 1 \mathrm{H}), 7.86-7.88(\mathrm{~d}, \mathrm{~J} 8.4 \mathrm{~Hz}, 1 \mathrm{H}), 8.02-8.04(\mathrm{~d}, \mathrm{~J} 8.4 \mathrm{~Hz}, 1 \mathrm{H})$, $8.24(\mathrm{~s}, 1 \mathrm{H}), 8.45(\mathrm{~s}, 1 \mathrm{H}) ;{ }^{13} \mathrm{C}$ NMR $(100 \mathrm{MHz}, \mathrm{CDCl} 3): \delta 41.0,65.8,92.2,118.0,123.6,127.2,127.9,128.0$, $128.4,130.9,131.5,139.9,140.4,148.4,149.8,157.4$; FTIR (film) cm cm $^{-1}$ HRMS (FAB) calcd for $\mathrm{C} 17 \mathrm{H} 11 \mathrm{Br} 2 \mathrm{CIN} 2 \mathrm{O} 2(\mathrm{M}+1) 468.8951$; found 468.8948.

\section{5-Bromo-8-(2-chloroquinolin-3-yl)-methyl-4H-[1,3]dioxino[5,4-c]pyridine (17).}

A mixture containing zinc chloride $(0.60 \mathrm{~mL}, 0.60 \mathrm{mmol}, 1.0 \mathrm{M}$ in diethylether), and sodium cyanoborohydride $(0.038 \mathrm{~g}, 0.60 \mathrm{mmol})$ was stirred at room temperature for one hour. A solution of $16(0.122 \mathrm{~g}, 0.26 \mathrm{mmol})$ in THF ( $3 \mathrm{~mL})$ added dropwise and the mixture was heated at reflux overnight. Saturated ammonium chloride was added and the aqueous mixture was extracted with dichloromethane. The combined extracts were dried over anhydrous sodium sulfate and concentrated. Purification by radial PLC (silica gel, EtOAc/hexanes, 10:90) yielded $0.064 \mathrm{~g}(63 \%)$ of 17 as yellow solid, mp 147-149 ${ }^{\circ} \mathrm{C} ;{ }^{1} \mathrm{H} \mathrm{NMR}\left(400 \mathrm{MHz}, \mathrm{CDCl}_{3}\right) \delta 4.13(\mathrm{~s}, 2 \mathrm{H}), 4.80(\mathrm{~s}$, $2 \mathrm{H}), 5.28(\mathrm{~s}, 2 \mathrm{H}), 7.52-7.56(\mathrm{t}, \mathrm{J} 7.6,7.6 \mathrm{~Hz}, 1 \mathrm{H}), 7.69-7.74(\mathrm{~m}, 2 \mathrm{H}), 7.78(\mathrm{~s}, 1 \mathrm{H}), 8.00-8.02(\mathrm{~d}, \mathrm{~J} 8.4 \mathrm{~Hz}, 1 \mathrm{H}), 8.07$ $(\mathrm{s}, 1 \mathrm{H}) ;{ }^{13} \mathrm{C} \mathrm{NMR}\left(100 \mathrm{MHz}, \mathrm{CDCl}_{3}\right) \delta 30.3,66.0,91.9,118.1,121.9,127.3,127.4,127.5,128.4,130.4,130.6$, 1378.0, 138.9, 146.8, 150.0, 151.2, 159.2; FTIR (film) 757, 875, 953, 1034, 1084, 1249, 1345, 1408, 1463, 1580, 1666, 1721, 2317, 2367, 2853, $2919 \mathrm{~cm}^{-1}$; HRMS (FAB) calcd for C17H12BrCIN2O2 (M+1) 390.99843; found 390.9843.

2-Bromo-4-methoxypyridine-5-carboxaldehyde (18). Method A. To a mixture containing 9 (0.65 g, 2.44 $\mathrm{mmol}$ ) and ethyl formate $(0.2 \mathrm{~mL}, 2.5 \mathrm{mmol})$ in $3 \mathrm{~mL}$ of THF at $-78{ }^{\circ} \mathrm{C}$ was added $n$-BuLi $(1.10 \mathrm{~mL}, 2.44 \mathrm{mmol}$, 2.22M in hexanes), and the mixture was stirred under nitrogen for 30 minutes. Saturated sodium bicarbonate was added and mixture was extracted with dichloromethane. The combined extracts were dried over anhydrous magnesium sulfate and concentrated. Purification by radial PLC (silica gel, EtOAc/hexanes, 5:95, 10:90) gave $0.249 \mathrm{~g}(47 \%)$ of 18 as a yellow solid, mp $112-114{ }^{\circ} \mathrm{C} ;{ }^{1} \mathrm{H}$ NMR $\left(300 \mathrm{MHz}, \mathrm{CDCl}_{3}\right) \delta 4.01(\mathrm{~s}, 3 \mathrm{H}), 7.14$ 
(s, 1H), 8.63 (s, 1H), $10.38(\mathrm{~s}, 1 \mathrm{H}) ;{ }^{13} \mathrm{C} \mathrm{NMR} \mathrm{(75} \mathrm{MHz,} \mathrm{CDCl} 3$ ) $\delta$ 56.6, 111.6, 120.3, 149.2, 151.1, 167.2, 188.0; FTIR (film) 876, 1018, 1079, 1258, 1287, 1362, 1401, 1432, 1474, 1580, 1694, 2855, 2926, 2954, 3103, 3360 $\mathrm{cm}^{-1}$; HRMS (FAB) calcd for $\mathrm{C}_{7} \mathrm{H}_{6} \mathrm{BrNO}_{2}(\mathrm{M}+1)$ 215.9660; found 215.9646 .

Method B. To a solution of 9 (56 mg, $0.21 \mathrm{mmol}$ ) in $1 \mathrm{~mL}$ of THF at $-78{ }^{\circ} \mathrm{C}$ under nitrogen was added $n$-BuLi $(0.1 \mathrm{~mL}, 0.23 \mathrm{mmol}, 2.34 \mathrm{M}$ in hexanes), and the mixture was stirred for 5 minutes. DMF $(0.07 \mathrm{~mL}, 0.84 \mathrm{mmol})$ was added and stirring was continued for 30 minutes. Saturated sodium bicarbonate was added and the mixture was extracted with dichloromethane. The combined extracts were dried over anhydrous magnesium sulfate, and concentrated. Purification by radial PLC (silica gel, EtOAc/hexanes, 10:90) gave $8 \mathrm{mg}(18 \%)$ of 18 as a yellow solid. The ${ }^{1} \mathrm{H}$ NMR was consistent with compound 18 made previously using method $\mathrm{A}$ above.

(6-Bromo-4-methoxypyridin-3-yl)-(2-chloroquinolin-3-yl)methanol (19). To a solution of 9 (0.752 g, 2.82 $\mathrm{mmol}$ ) in THF $(5.0 \mathrm{~mL})$ was added isopropylmagnesium chloride $(1.70 \mathrm{~mL}, 3.40 \mathrm{mmol}, 2 \mathrm{M}$ in THF). The mixture was stirred at room temperature for one hour. A solution of 2-chloroquinoline-3-carboxaldehyde (0.557 g, $2.91 \mathrm{mmol})$ in THF $(10 \mathrm{~mL})$ was added dropwise, and stirring was continued at room temperature overnight under nitrogen. Saturated sodium bicarbonate was added and the mixture was extracted with dichloromethane. The combined extracts were dried over anhydrous magnesium sulfate and concentrated. Purification by radial PLC (silica gel, EtOAc/hexanes, 5:95) yielded $0.739 \mathrm{~g}(69 \%)$ of 19 as a yellow solid, mp 182-184 ${ }^{\circ} \mathrm{C} ;{ }^{1} \mathrm{H}$ NMR (400 MHz, $\left.\mathrm{CDCl}_{3}\right) \delta 3.49-3.50(\mathrm{~d}, J 4.0 \mathrm{~Hz}, 1 \mathrm{H}), 3.85(\mathrm{~s}, 3 \mathrm{H}), 6.45-6.46(\mathrm{~d}, J 4.0 \mathrm{~Hz}, 1 \mathrm{H})$, 7.56-7.59 (t, J 7.6, 7.2 Hz, 1H), 7.72-7.76 (t, J 8.0, 6.8 Hz, 1H), 7.81-7.83 (d, J 8.0Hz, 1H), 8.00-8.02 (d, J $8.0 \mathrm{~Hz}$, $1 \mathrm{H}), 8.12(\mathrm{~s}, 1 \mathrm{H}), 8.26(\mathrm{~s}, 1 \mathrm{H}) ;{ }^{13} \mathrm{C} N M R\left(100 \mathrm{MHz}, \mathrm{CDCl}_{3}\right) \delta 56.3,66.3,110.5,125.8,127.3,127.6,128.0,128.3$, 130.9, 133.4, 137.3, 143.3, 147.3, 149.0, 149.5, 164.1; FTIR (film) 736, 754, 781, 876, 1024, 1083, 1138, 1234, $1267,1324,1399,1434,1486,1563,1584,1710,2847,2939,3063,3271 \mathrm{~cm}^{-1}$; HRMS (FAB) calcd for $\mathrm{C}_{16} \mathrm{H}_{12} \mathrm{BrClN}_{2} \mathrm{O}_{2}(\mathrm{M}+1) 378.9849$; found 378.9852 .

(3,6-Dibromo-4-iodopyridinyl-2-yl)-methanol (21). A solution of diisopropylamine (1.10 $\mathrm{mL}, 7.85 \mathrm{mmol}) \mathrm{in}$ THF (30 mL) at $-20^{\circ} \mathrm{C}$ was treated with $n$-BuLi $(3.4 \mathrm{~mL}, 7.96 \mathrm{mmol}, 2.34 \mathrm{M}$ in hexanes). The mixture was stirred for one hour under nitrogen and then cooled to $-78^{\circ} \mathrm{C}$. A solution of $8 \mathrm{a}(2.40 \mathrm{~g}, 6.62 \mathrm{mmol})$ in THF (10 mL) was added dropwise and the mixture was stirred for 5 minutes. Neat ethyl formate $(3.0 \mathrm{~mL}, 37.14 \mathrm{mmol}) \mathrm{was}$ added and the mixture was stirred for 30 minutes. Methanol $(10 \mathrm{~mL})$ and $\mathrm{NaBH}_{4}(0.75 \mathrm{~g}, 19.83 \mathrm{mmol})$ were added. The cooling bath was removed and stirring was continued at room temperature for 25 minutes. The mixture was extracted with dichloromethane. The combined extracts were washed with saturated sodium bicarbonate and dried over anhydrous magnesium sulfate. Concentration and purification by radial PLC (silica gel, EtOAc/hexanes, 10:90) yielded $1.689 \mathrm{~g}(65 \%)$ of 21 as a white solid, mp 168-172 ${ }^{\circ} \mathrm{C} ;{ }^{1} \mathrm{H} \mathrm{NMR}(300 \mathrm{MHz}$, $\mathrm{DMSOd}_{6}$ ) $\delta 4.45-4.47(\mathrm{~d}, 2 \mathrm{H}, J 5.4 \mathrm{~Hz}), 5.88-5.91(\mathrm{t}, 1 \mathrm{H}, J 6.0,5.4 \mathrm{~Hz}), 7.60(\mathrm{~s}, 1 \mathrm{H}) ;{ }^{13} \mathrm{C} \mathrm{NMR}\left(75 \mathrm{MHz}, \mathrm{DMSOd}_{6}\right)$ $\delta$ 63.6, 125.2, 125.4, 127.4, 138.9, 155.6; FTIR (DMSO) 765, 826, 1001, 1025, 1649, 2126, 2253, 2796, 2923, $3410 \mathrm{~cm}^{-1}$; HRMS (FAB) calcd for $\mathrm{C}_{6} \mathrm{H}_{4} \mathrm{Br}_{2} \mathrm{INO}_{2}(\mathrm{M}+1)$ 391.7783; found. 391.7795. Structure was confirmed by Xray crystallography.

(3,6-Dibromo-2-iodopyridin-4-yl)methanol (22a) or (2,6-Dibromo-3-iodopyridin-4-yl)methanol (22b). To a solution of 2,2,6,6-tetramethylpiperidine $(0.51 \mathrm{~mL}, 3.02 \mathrm{mmol})$ in THF $(3 \mathrm{~mL})$ at $-20{ }^{\circ} \mathrm{C}$ was added with $n$-BuLi $(1.51 \mathrm{~mL}, 3.02 \mathrm{mmol}, 2.0 \mathrm{M}$ in hexanes). The mixture was stirred for 30 minutes under argon and then cooled to $-78{ }^{\circ} \mathrm{C}$. A solution of $8 \mathrm{a}(1.0 \mathrm{~g}, 2.76 \mathrm{mmol})$ in THF $(5 \mathrm{~mL})$ was added dropwise and stirring was continued for 30 minutes. DMF $(0.65 \mathrm{~mL}, 8.39 \mathrm{mmol})$ was added dropwise and the mixture was stirred at $-78{ }^{\circ} \mathrm{C}$ for 30 minutes. Saturated sodium bicarbonate was added and mixture was extracted with diethyl ether. The combined extracts were washed with brine, dried over anhydrous magnesium sulfate, and concentrated. The residue was dissolved in dichloromethane/ethanol $(25 \mathrm{~mL} / 25 \mathrm{~mL})$. Sodium borohydride $(0.104 \mathrm{~g}, 3.02 \mathrm{mmol})$ was added and the mixture was stirred for 30 minutes at room temperature. Water was added and the 
mixture was extracted with dichloromethane. The combined extracts were washed with brine and dried over anhydrous magnesium sulfate. Concentration and purification by radial PLC (silica gel, EtOAc/hexanes, 20:80)

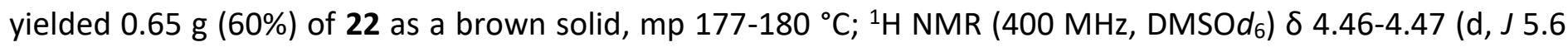
$\mathrm{Hz}, 2 \mathrm{H}), 5.89-5.92(\mathrm{t}, J 5.6,5.2 \mathrm{~Hz}, 1 \mathrm{H}), 7.61(\mathrm{~s}, 1 \mathrm{H}) ;{ }^{13} \mathrm{C} N M R(100 \mathrm{MHz}, \mathrm{DMSOd}$ ) $\delta$ 63.6, 125.2, 125.4, 127.4, 138.9, 155.6; FTIR (film) 762, 879, 1015, 1071, 1112, 1193, 1316, 1365, 1439, 1512, 1552, $3296 \mathrm{~cm}^{-1}$; HRMS (FAB) calcd for $\mathrm{C}_{6} \mathrm{H}_{4} \mathrm{Br}_{2} \mathrm{INO}(\mathrm{M}+1) 391.7783$; found 391.7795 .

\section{3,6-Dibromo-2-iodo-4-methoxymethoxymethylpyridine (23a) or (2,6-Dibromo-3-iodo-4-}

methoxymethoxymethylpyridine (23b). A mixture containing 22 (2.447 g, 6.23mmol), $N, N$-diisopropylamine $(4.40 \mathrm{~mL}, 25.26 \mathrm{mmol})$, and potassium iodide $(0.052 \mathrm{~g}, 0.31 \mathrm{mmol})$ in THF $(20 \mathrm{~mL})$ at $-20{ }^{\circ} \mathrm{C}$ was treated with methoxymethyl chloride $(1.40 \mathrm{~mL}, 17.33 \mathrm{mmol})$. The mixture was heated at $50{ }^{\circ} \mathrm{C}$ overnight and then cooled to room temperature. Saturated sodium bicarbonate was added and the mixture was extracted with ethyl acetate. The combined extracts were washed with brine and dried over anhydrous magnesium sulfate. Concentration and purification by radial PLC (silica gel, EtOAc/hexane, 5:95) yielded $2.258 \mathrm{~g}$ (83\%) of 23 as a yellow oil; ${ }^{1} \mathrm{H}$ NMR (400 MHz, $\left.\mathrm{CDCl}_{3}\right) \delta 3.42(\mathrm{~s}, 3 \mathrm{H}), 4.56(\mathrm{~s}, 2 \mathrm{H}), 4.79(\mathrm{~s}, 2 \mathrm{H}), 7.63(\mathrm{~s}, 1 \mathrm{H}) ;{ }^{13} \mathrm{C} \mathrm{NMR}(100 \mathrm{MHz}$, $\mathrm{CDCl}_{3}$ ) $\delta$ 56.1, 69.1, 96.6, 123.6, 126.0, 127.8, 139.6, 151.2; FTIR (film) 762, 920, 970, 1054, 1113, 1152, 1198, $1310,1354,1441,1513,1551,2776,2848,2888,2948,3113 \mathrm{~cm}^{-1}$; HRMS (FAB) calcd for $\mathrm{C}_{8} \mathrm{H}_{8} \mathrm{Br}_{2} \mathrm{INO}_{2}(\mathrm{M}+1)$ 435.8045; found 435.8036 .

2,6-Dibromo-4-methoxymethoxymethylpyridin-3-ol (24). A solution of 23 (3.932 g, $9.00 \mathrm{mmol}$ ) in THF (20 mL) at $-78{ }^{\circ} \mathrm{C}$ was treated with $n$-BuLi $(4.70 \mathrm{~mL}, 9.87 \mathrm{mmol})$, and the mixture was stirred under nitrogen for 5 minutes. Trimethylborate $(2.20 \mathrm{~mL}, 19.73 \mathrm{mmol})$ was added dropwise and the mixture was allowed to slowly warm to room temperature overnight. After cooling to $-20^{\circ} \mathrm{C}$, peracetic acid $(5.20 \mathrm{~mL}, 21.9 \mathrm{mmol})$ was added and stirring was continued for 2 hours. Aqueous $10 \%$ sodium bisulfite $(50 \mathrm{~mL})$ was added and the aqueous mixture was extracted with dichloromethane. The combined extracts were filtered through a pad of anhydrous magnesium sulfate. Concentration and purification by radial PLC (silica gel, EtOAc/hexane, 20:80) yielded $2.35 \mathrm{~g}(80 \%)$ of 24 as an orange-yellow solid, mp $113-114{ }^{\circ} \mathrm{C} ;{ }^{1} \mathrm{H} \mathrm{NMR}\left(400 \mathrm{MHz}, \mathrm{CDCl}_{3}\right) \delta 3.44(\mathrm{~s}, 3 \mathrm{H})$, 4.69 (s, 2H), 4.78 (s, 2H), 6.49 (s, 1H), 7.41 (s, 1H); $\left.{ }^{13} \mathrm{C} \mathrm{NMR} \mathrm{(100} \mathrm{MHz,} \mathrm{CDCl}\right) \delta 56.1,64.5,96.6,126.4,129.2$, 130.1, 136.7, 147.4; FTIR (film) 698, 899, 921, 1050, 1115, 1151, 1213, 1292, 1351, 1435, 1556, 1579, 1642, 1722, 2849, 2920, 2953, $3303 \mathrm{~cm}^{-1}$; Anal. Calcd for $\mathrm{C}_{8} \mathrm{H}_{9} \mathrm{Br}_{2} \mathrm{NO}_{3}$ : C, 29.39; H, 2.77; N, 4.28. Found: C, 29.50; $\mathrm{H}$, 2.76; N, 4.15. Structure was confirmed by X-ray crystallographic analysis.

6,8-Dibromo-4H-[1,3]dioxino[4,5-c]pyridine (25). To a solution of $24(0.454 \mathrm{~g}, 1.39 \mathrm{mmol})$ in anhydrous dichloromethane $(10 \mathrm{~mL})$ was added anhydrous boron trifluoride diethyl etherate $(0.25 \mathrm{~mL}, 2.03 \mathrm{mmol})$. The mixture was stirred at room temperature under nitrogen overnight. Saturated sodium bicarbonate was added and the mixture was extracted with dichloromethane. The combined extracts were washed with brine and dried over anhydrous magnesium sulfate. Concentration and purification by radial PLC (silica gel, EtOAc/hexane, 5:95) yielded $0.203 \mathrm{~g}(50 \%)$ of 25 as a white solid, mp 129- $131{ }^{\circ} \mathrm{C} ;{ }^{1} \mathrm{H} \mathrm{NMR}\left(400 \mathrm{MHz}, \mathrm{CDCl}_{3}\right) \delta$

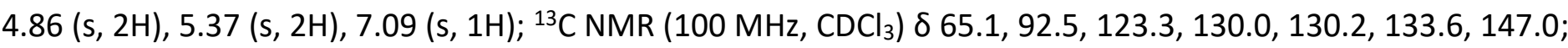
FTIR ( film) 656, 820, 954, 1084, 1109, 1140, 1210, 1233, 1269, 1323, 1372, 1396, 1433, 1549, 2853, 2922, $2956 \mathrm{~cm}^{-1}$; Anal. Calcd for $\mathrm{C}_{7} \mathrm{H}_{5} \mathrm{Br}_{2} \mathrm{NO}_{2}$ : C, 28.51, H, 1.71, N, 4.75. Found: C, 28.57, H, 1.76, N, 4.53.

6-Bromo-4H[1,3]dioxino[4,5-c]pyridine (26). To a solution of 25 (45 mg, $0.15 \mathrm{mmol})$ in THF (5 mL) at $-100{ }^{\circ} \mathrm{C}$ was added $n$-BuLi $(0.08 \mathrm{~mL}, 0.17 \mathrm{mmol}, 2.10 \mathrm{M}$ in hexanes), and the mixture was stirred for 10 minutes. Saturated sodium bicarbonate $(3 \mathrm{~mL})$ was added and the mixture was extracted with ethyl acetate. The combined extracts were washed with brine, dried over anhydrous magnesium sulfate, and concentrated to yield $26.2 \mathrm{mg}$ (80\%) of 26 as a yellow gum; $\left.{ }^{1} \mathrm{H} \mathrm{NMR} \mathrm{(400} \mathrm{MHz}, \mathrm{CDCl}_{3}\right) \delta 4.87(\mathrm{~s}, 2 \mathrm{H}), 5.27(\mathrm{~s}, 2 \mathrm{H}), 7.12(\mathrm{~s}, 1 \mathrm{H})$, $8.03(\mathrm{~s}, 1 \mathrm{H}) ;{ }^{13} \mathrm{C} \mathrm{NMR}\left(100 \mathrm{MHz}, \mathrm{CDCl}_{3}\right) \delta 65.1,91.8,123.7,132.4,132.8,139.5,149.4 ;$ FTIR (film) 734, 879, 
$952,978,1074,1138,1209,1231,1261,1326,1379,1466,1716,2859,2899,2929,2965,3026,3050 \mathrm{~cm}^{-1}$; HRMS (FAB) calcd for $\mathrm{C}_{7} \mathrm{H}_{6} \mathrm{BrNO}_{2}(\mathrm{M}+1)$ 215.9660; found 215.9646 .

\section{Acknowledgements}

The authors would like to acknowledge financial support by North Carolina State University. I.D. Bori would like to thank the National GEM Consortium and North Carolina State University for funding of the National GEM Fellowship to support his graduate education at North Carolina State University.

\section{Supplementary Material}

Supporting Information Available: Copies of ${ }^{1} \mathrm{H}$ and ${ }^{13} \mathrm{C}$ NMR spectra of compounds 2-5, 8a-e and 9-26. Copies of X-ray crystallography data for compounds 8a, 10, 12, 17, 21, and 24.

\section{References}

1. Hay, D. A.; Rogers, C. M.; Fedorov, O.; Tallant, C.; Martin, S.; Monteiro, O. P.; Müller, S.; Knapp, S.; Schofield, C. J.; Brennan, P. E. MedChemComm 2015, 6, 1381-1386.

https://doi.org/10.1039/C5MD00152H

2. Chen, P.; Chaikuad, A.; Bamborough, P.; Bantscheff, M.; Bountra, C.; Chung, C.-w.; Fedorov, O.; Grandi, P.; Jung, D.; Lesniak, R.; Lindon, M.; Müller, S.; Philpott, M.; Prinjha, R.; Rogers, C.; Selenski, C.; Tallant, C.; Werner, T.; Willson, T. M.; Knapp, S.; Drewry, D. H. J. Med. Chem. 2016, 59, 1410-1424. https://doi.org/10.1021/acs.jmedchem.5b00209

3. Renshaw, R. R.; Conn, R. C. J. Am. Chem. Soc. 1937, 59, 297-301. https://doi.org/10.1021/ja01281a021

4. Zych, D.; Kurpanik, A.; Slodek, A.; Maroń, A.; Pająk, M.; Szafraniec-Gorol, G.; Matussek, M.; Krompiec, S.; Schab-Balcerzak, E.; Kotowicz, S.; Siwy, M.; Smolarek, K.; Maćkowski, S.; Danikiewicz, W. Chem. Eur. J. 2017, 23, 15746-15758. https://doi.org/10.1002/chem.201703324

5. Hajhussein, A. N.; Abuzahra, L. S.; Pietrzak, A.; Sadek, M. F.; Ali, M. O.; Wojciechowski, J.; Friedli, A. C.; Kaszyński, P. Arkivoc 2018, (vii), 225-235. https://doi.org/10.24820/ark.5550190.p010.700

6. Deschenaux, R.; Donnio, B.; Rheinwald, G.; Stauffer, F.; Süss-Fink, G.; Velker, J. J. Chem. Soc., Dalton Trans. 1997, 4351-4355. https://doi.org/10.1039/a704712f

7. Abdullah, N.; Mohd Said, S.; Halid, Y. Y.; Megat Hasnan, M. M. I.; Sharmin, N.; Mat Hussin, S. A.; Nik Ibrahim, N. M. J.; Nordin, A. R.; Safiin, N. A.; Anuar, N. S. J. Coord. Chem. 2016, 69, 2954-2971. https://doi.org/10.1080/00958972.2016.1221504

8. Cartwright, K. C.; Joseph, E.; Comadoll, C. G.; Tunge, J. A. Chem. Eur. J. 2020, 26, 12454-12471. https://doi.org/10.1002/chem.202001952 
9. Abe, H.; Machiguchi, H.; Matsumoto,S.; Inouye, M. J. Org. Chem. 2008, 73, 4650-4661. https://doi.org/10.1021/jo800599w

10. Chattopadhyay, A. K.; Hanessian, S. Chem. Commun. 2015, 51, 16450-16467. https://doi.org/10.1039/C5CC05892A

11. Comins, D. L.; Tsukanov, S. "Applications to Alkaloid Synthesis," in Pyridines-Best Synthetic Methods, Elsevier: Oxford, 2013, 459-496.

https://doi.org/10.1016/B978-0-12-385235-9.00006-0

12. Comins, D. L.; LaMunyon, D. H. Tetrahedron Lett. 1988, 29, 773-776.

https://doi.org/10.1016/S0040-4039(00)80206-3

13. Comins, D. L.; Killpack, M. O. J. Org. Chem. 1990, 55, 69-73.

https://pubs.acs.org/doi/10.1021/jo016064p

14. Trécourt, F.; Mallet, M.; Mongin, O.; Gervais, B.; Quéguiner, G. Tetrahedron 1993, 49, 8373-8380. https://doi.org/10.1016/S0040-4020(01)81920-7

15. Cuperly, D.; Gros, P.; Fort, Y. J. Org. Chem. 2002, 67, 1, 238-24.

https://doi.org/10.1021/jo016064p

16. For a similar conversion, see: Comins, D. L.; Nolan, J. M. Org. Lett. 2001, 3, 4255-4257. https://doi.org/10.1021/ol0169271

17. Gribble, G. W.; Saulnier, M. G. Tetrahedron Lett. 1980, 21, 4137-4140.

https://doi.org/10.1016/S0040-4039(00)93671-2

18. Gribble, G. W.; Saulnier, M. G. Heterocycles 1993, 35, 151-169.

https://doi.org/10.3987/COM-92-S1

19. Mallet, M.; Quéguiner, G. Tetrahedron 1982, 38, 3035-3042.

https://doi.org/10.1016/0040-4020(82)80190-7

20. Gross, P.; Choppin, S.; Fort, Y. J. Org. Chem. 2003, 68, 2243-2247.

https://doi.org/10.1021/jo026559u

21. Parham, W.E.; Piccirli, R.M. J. Org. Chem. 1977, 42, 257-260.

https://doi.org/10.1021/jo00422a019

22. Trécourt, F.; Breton, G.; Bonnet, V.; Mongin, F.; Marsais, F.; Quéguiner, G. Tetrahedron Lett. 1999, 40, 4339-4342.

https://doi.org/10.1016/S0040-4039(99)00789-3

23. Iranpoor, N.; Firouzabadi, H.; Aghapour, Gh.; Vaez zadeh, A.R. Tetrahedron 2002, 58, 8689-8693. https://doi.org/10.1016/S0040-4020(02)01089-X

24. Kim, S.; Kim, Y. J.; Ahn, K. H. Tetrahedron Lett. 1983, 24, 3369-3372. https://doi.org/10.1016/S0040-4039(00)86272-3

25. Mallet, M.; Branger, G.; Marsais, F.; Quéguiner, G. J. Organomet. Chem. 1990, 382, 319-332. https://doi.org/10.1016/0022-328X(90)80210-Q

26. Duan, X-F.; Zhang, Z-B. Heterocycles, 2005, 65, 2005-2012. https://doi.org/10.3987/REV-05-598 